\title{
A Novel Method of Light Weighting Aluminium Using Magnesium Syntactic Composite Core
}

\author{
Penchal Reddy Matli ${ }^{1}$, Joshua Goh Yong Sheng ${ }^{1}$, Gururaj Parande ${ }^{1}$ (), Vyasaraj Manakari ${ }^{1}$ (i), \\ Beng Wah Chua ${ }^{2}$, Stephen Chee Khuen Wong ${ }^{2}$ and Manoj Gupta ${ }^{1, *(1)}$ \\ 1 Department of Mechanical Engineering, National University of Singapore, Singapore 117576, Singapore; \\ mpeprm@nus.edu.sg (P.R.M.); e0177106@u.nus.edu (J.G.Y.S.); gururaj.parande@u.nus.edu (G.P.); \\ mbvyasaraj@u.nus.edu (V.M.) \\ 2 Singapore Institute of Manufacturing Technology, Singapore 138634, Singapore; \\ bwchua@simtech.a-star.edu.sg (B.W.C.); ckwong@simtech.a-star.edu.sg (S.C.K.W.) \\ * Correspondence: mpegm@nus.edu.sg; Tel.: +65-65166358
}

Received: 2 September 2020; Accepted: 8 October 2020; Published: 10 October 2020

\begin{abstract}
In this study, hybrid composite consisting of aluminium (Al) shell and magnesium/glass microballoon (Mg-20 wt.\% GMB) syntactic composite core was fabricated in a shell-core pattern by combining powder metallurgy and disintegrated melt deposition (DMD) techniques. Physical, microstructural and mechanical properties of as-cast $\mathrm{Al}$ and $\mathrm{Al} / \mathrm{Mg}$-20GMB hybrid composite were examined. Approximately $13 \%$ reduction in density (with respect to aluminium) was realized through the use of a syntactic composite core. Microstructural investigations revealed reasonable interfacial integrity between aluminium shell and $\mathrm{Mg}-\mathrm{GMB}$ core material and the presence of $\mathrm{Al}, \mathrm{Mg}$ and $\mathrm{GMB}$ phases. The interface region showed a hardness of $109 \pm 2 \mathrm{Hv}$ in comparison to the hardness of $\mathrm{Al}$ shell region $(68 \pm 4 \mathrm{Hv})$ and $\mathrm{Mg}$-20GMB core region $(174 \pm 5 \mathrm{Hv})$. In comparison to as-cast $\mathrm{Al}$, the yield strength and ultimate compressive strength of the as-cast $\mathrm{Al} / \mathrm{Mg}$-20GMB hybrid composite increased by $\sim 65.4 \%$ and $\sim 60 \%$, respectively. Further, the energy absorption under compressive loading for the $\mathrm{Al} / \mathrm{Mg}-20 \mathrm{GMB}$ hybrid composite was $\sim 26 \%$ higher compared to pure Al. This study validated that $\mathrm{Al} / \mathrm{Mg}$-20GMB hybrid composite with superior absolute and specific mechanical properties can be fabricated and used for weight critical applications.
\end{abstract}

Keywords: aluminium; magnesium; syntactic foam; hybrid composite; microstructure; compression

\section{Introduction}

Hybrid composites are emerging as an efficient superior alternative to traditional metal matrix composites (MMCs) in fulfilling the light-weighting requirements for various engineering applications including automotive, aerospace, and electronic sectors [1,2]. Current engineering applications demand materials that are stronger, lighter, and cost-effective. Hybrid composites provide an opportunity to tailor a wide range of properties like density, strength, modulus, damping and thermal properties in a way that is different from conventional composites. In this regard, aluminium (Al)- and magnesium (Mg)-based composites have garnered significant interest in the aerospace and automotive sectors as they exhibit excellent combination of low density, superior thermal and mechanical properties [3-5]. As a result, researchers have focused on the fabrication of aluminium $(\mathrm{Al}) /$ magnesium $(\mathrm{Mg})$ based bimetal/hybrid composites to synergize the excellent combination of properties from both $\mathrm{Al}$ and $\mathrm{Mg}$ alloys [6-8]. One of the best-known examples of aluminium-magnesium composite is the BMW aluminium-magnesium engine block where magnesium is cast over the aluminium core resulting in an overall weight reduction of $\sim 24 \%$ compared to conventional aluminium block. Since aluminium alloys and composites have reached their performance plateau and no further reduction in density is possible, 
$\mathrm{Al} / \mathrm{Mg}$ hybrid composites can easily find applications in replacing automotive components made of $\mathrm{Al}$ such as transfer cases, transmission components and body structural braces to reduce vehicle weight and improve performance [2,9].

Recently, the importance of Al matrix hybrid composites (AMHC's) is progressively increasing as they are capable of enhancing hardness, strength and light weighting at low manufacturing costs [4,10-12]. Besides, $\mathrm{Al}$ and $\mathrm{Mg}$ are the most widely used engineering light metals with theoretical densities of $2.7 \mathrm{~g} / \mathrm{cc}$ and $1.74 \mathrm{~g} / \mathrm{cc}$, respectively [13]. The high specific strength, good castability, and low density have benefited Mg-based materials whereas its wide scale applicability is limited by low ductility, corrosion susceptibility, and rapid loss of strength at higher temperatures [14]. On the other hand, Al-based materials can maintain their strength at elevated temperatures and possess excellent corrosion resistance $[15,16]$. Further weight reduction can be realized by reinforcing hollow particles into $\mathrm{Al}$ and $\mathrm{Mg}$ matrices, thereby reducing the effective volume percentage of the matrix leading to lightweight composite structures known as syntactic foams [17]. Incorporating porosity through hollow particles instead of embedding air/gas voids, provides a reinforcing effect to each pore and imparts properties similar or superior to what would be found in monolithic cellular materials, in particular metallic foams [18]. The incorporation of porosity in a material makes the material lightweight and enhances the compressibility. Aluminium foams have been used successfully as stiffener and crash absorbers in automotive applications and as backing plates for mirrors in aerospace owing to their lightweight, excellent damping and energy absorption capabilities [17]. Although syntactic foams have higher densities, they have superior performance in terms of compressive strength, stiffness and energy absorption with respect to conventional foams and can advantageously replace most of the foams based on their better performance in applications related to energy absorption, lightweight and high stiffness. A promising application of metal matrix syntactic foam core has been explored by Rolls-Royce Plc in the construction of aerofoils for compressor blades in gas turbine engine, wherein the aerofoil is made of laminate with two metal sheets and syntactic foam core [19]. Naturally available fillers, such as cenospheres, have numerous surface defects as compared to engineered microballoons [20,21], and hence engineered GMBs are chosen in the current work for the development of Mg-GMB syntactic foam core. Our earlier works on Mg-GMB syntactic composite foams revealed the maximum enhancement in the yield strength of $\mathrm{Mg}$ with considerable reduction in density ( 13\%) [20].

Due to new engineering requirements and diversification of applications, it is increasingly becoming difficult for traditional metals, alloys and composites to satisfy various properties requirements at low cost [22,23]. Provided the choice of two materials and their integration is good, unique combination of properties can be realized from such composites. For lightweight applications, the selection of aluminium and magnesium is natural for creating bimetallic/hybrid composites. As the cost of Al-alloys has decreased over time, the focus on Al has progressively increased. Al has better solidification characteristics when compared to other cast metals such as copper alloys [24]. Casting is one of the low cost fabrication techniques for fabricating Al metal components and caters to $98 \%$ of structural applications of $\mathrm{Al}[15,25]$. Solid-liquid compound casting has been effectively used to develop hybrid composite wherein liquid metal is poured on solid metal. This technique has been employed to fabricate various bimetallic systems, such as $\mathrm{Mg} / \mathrm{Mg}$ [26], Al/Mg [27-29], Al/Ti [30], Al/Cu [24], Al/AZ91D [31], Al/Al [32,33], etc. These studies largely reported the metallurgical, mechanical, and tribological properties of the systems. Song et al. [25] fabricated $\mathrm{Al} / \mathrm{Mg}$ compound materials by a solid-liquid bonding method and good bonding between the two matrices were observed with the interface layer primarily consisting of $\mathrm{Al}_{12} \mathrm{Mg}_{17}$ and $\mathrm{Al}_{3} \mathrm{Mg}_{2}$. Hajjari et al. [29] used compound casting to join aluminium to magnesium. Due to Al-Mg diffusion, the intermetallic compounds of two types, i.e., $\mathrm{Al}_{3} \mathrm{Mg}_{2}$ and $\mathrm{Al}_{12} \mathrm{Mg}_{17}$ were observed. Nie et al. [30] investigated the bonding mechanism and mechanical behaviour of $\mathrm{Al} / \mathrm{Ti}$ metallic composites by insert moulding. They reported good metallurgical bonding between $\mathrm{Al}$ and Ti. Maximum hardness was observed for the compact interface sublayer. The experimental results showed that the improvement of the shear strength of the interface layer was about 23\% when compared to the $\mathrm{Al}$ matrix. He et al. [31] 
successfully developed Al-Al bimetals using solid-liquid compound casting. The tensile strength was enhanced by $\sim 7 \%$ from $145 \mathrm{MPa}$ to $155 \mathrm{MPa}$ when compared to that fabricated by gravity casting.

However, in the open literature, there are no studies on $\mathrm{Al} / \mathrm{Mg}$ hybrid composites with a syntactic composite core which are fabricated by combining powder metallurgy and liquid metallurgy approach. Thus, the main objectives of the current study were: (i) to prepare a Mg-20GMB syntactic composite core material using a combination of cold compaction followed by hot-extrusion, (ii) to synthesize an Al-based hybrid composite with Mg-20GMB as core using a combination of an innovative disintegrated melt deposition (DMD) method and bottom-pouring and (iii) study the physical, microstructural and mechanical properties.

\section{Materials and Methods}

\subsection{Materials and Methods}

In this study, magnesium turnings (99.9\% purity ACROS Organics, Morris Plains, NJ, USA), magnesium powder (98.5\% purity, size range of $60-300 \mu \mathrm{m}$, Merck, Darmstadt, Germany), and aluminium lumps ( $99.9 \%$ purity, Alfa Aesar, Tewksbury, MA, USA) were used as the base materials. Hollow glass microballoon (GMB) particles with a density of $\sim 1.05 \mathrm{~g} / \mathrm{cc}$, mean particle diameter of 11 $\mu \mathrm{m}$ and a wall thickness of $\sim 0.8 \mu \mathrm{m}$ were procured from Sigma Aldrich, Singapore. Pure $\mathrm{Al}$ as control and $\mathrm{Al} / \mathrm{Mg}-20 \mathrm{GMB}$ hybrid composite was synthesized.

\subsection{Processing}

To fabricate Mg-20GMB syntactic composite core material, Mg powder and $20 \mathrm{wt} . \%$ ( 42 vol.\%) of Glass Microballoons (GMB) powder were weighed and blended using planetary ball mill (Retsch PM400, Haan, Germany) at a speed of $200 \mathrm{rpm}$ for $120 \mathrm{~min}$ to ensure the uniform dispersion of GMB particles into the Mg matrix. At a pressure of $510 \mathrm{MPa}$ (97 bars), the blended powder was then uniaxially compacted into cylindrical billets of $35 \mathrm{~mm}$ diameter and $40 \mathrm{~mm}$ length, as shown in Figure 1a. Prior to hot extrusion, the compacted billets were homogenized at $250{ }^{\circ} \mathrm{C}$ for $1 \mathrm{~h}$ and subsequently extruded at $200{ }^{\circ} \mathrm{C}$ using a 150-ton hydraulic press. The extrusion ratio of 3.06:1 was maintained to obtain rods of $20 \mathrm{~mm}$ in diameter at a hydraulic pressure of $6.89 \mathrm{MPa}(1000 \mathrm{psi})$, as shown in Figure 1b.
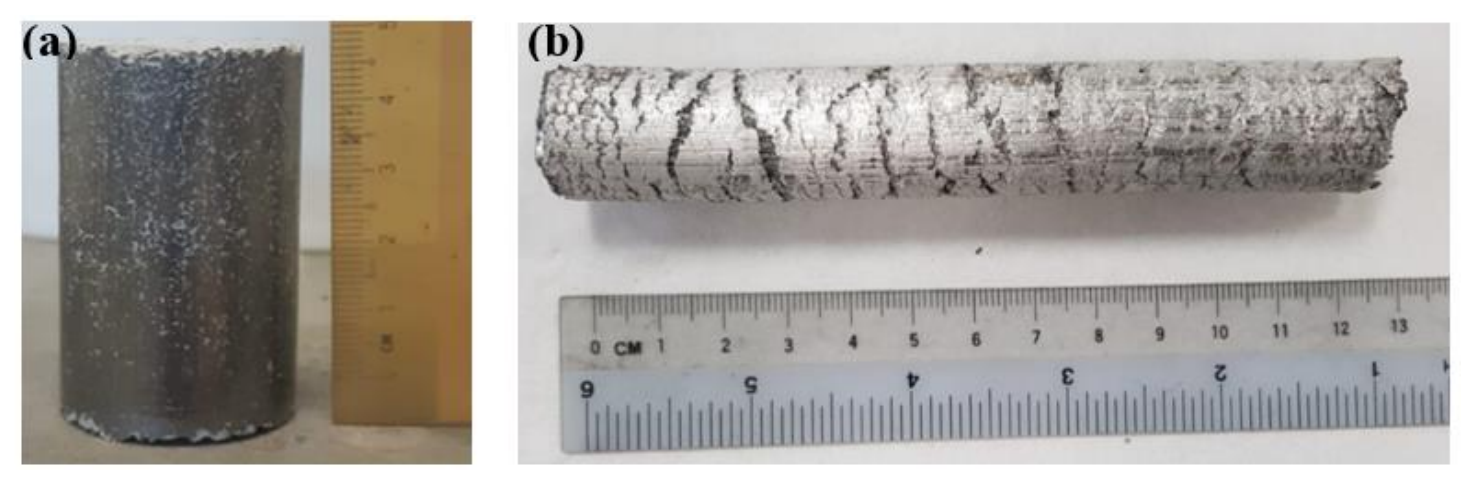

Figure 1. (a) Compacted billet and (b) extruded rod of Mg-20GMB syntactic composite core material.

Figure 2 illustrates the schematic of processing of the as-cast pure $\mathrm{Al}$ and Al-based hybrid composite, with disintegrated melt deposition (DMD) process in step 2. The DMD process has been successfully employed to prepare various $\mathrm{Al}$ and $\mathrm{Mg}$-based composite for more than two decades [34]. DMD is energy efficient and produces almost no scrap when compared to conventional casting methods. Further, DMD can also able to produce composites of finer grain size and with uniform distribution of reinforcements irrespective of their length scale. Moreover, argon gas was used as a protective atmosphere during DMD process which is non-poisonous and eco-friendly. 

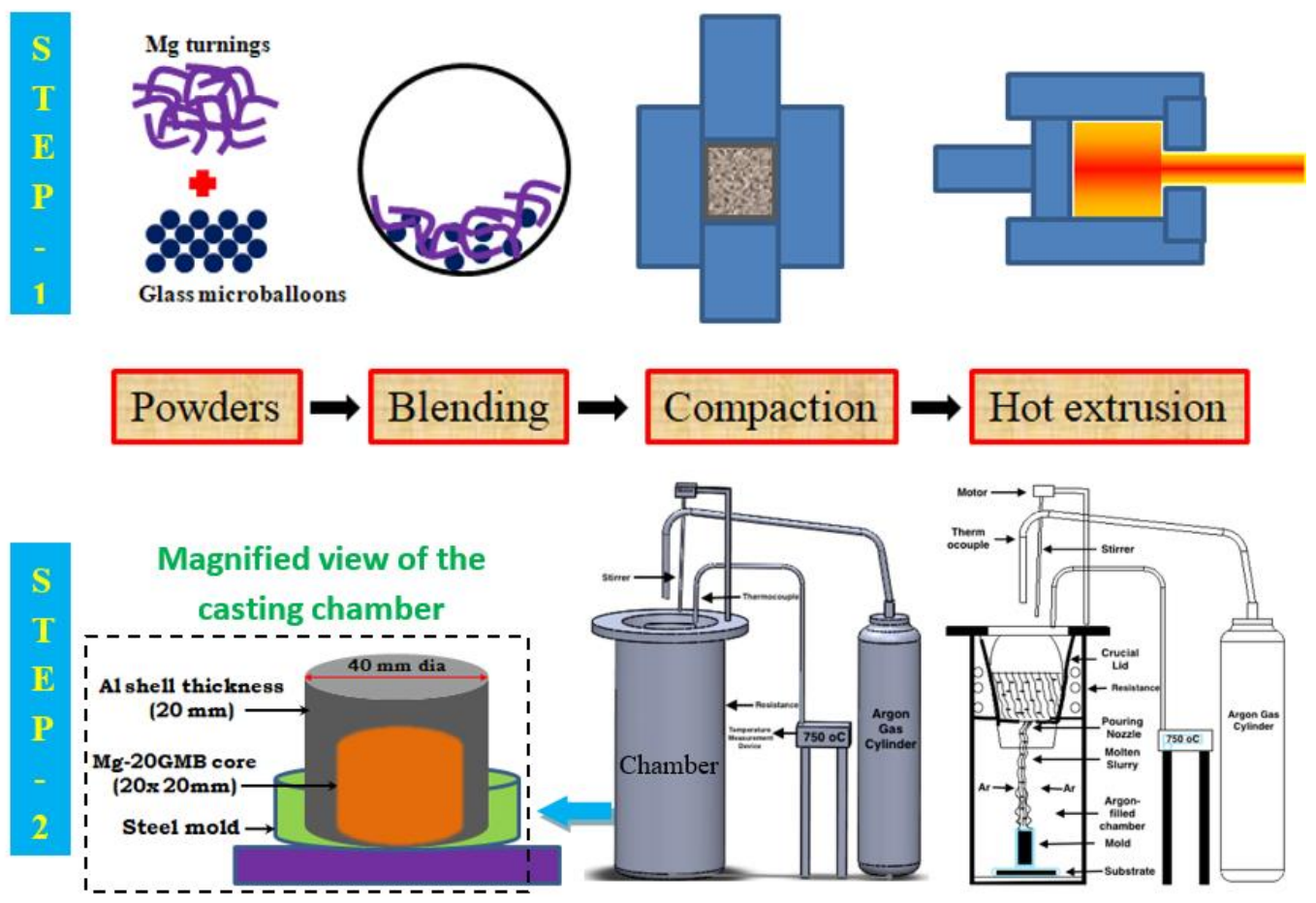

Figure 2. Schematic of fabricating the hybrid composite. Step-1: Synthesis of Mg-20GMB syntactic composite core material. Step-2: Fabrication of as-cast Al/Mg-20GMB composite by DMD method.

The Al lumps were considered as a base material and the extruded Mg-20GMB syntactic composite was used as a core material in the second step. At the centre of the steel mould the extruded Mg-20GMB syntactic composite core (20 mm diameter and $20 \mathrm{~mm}$ length) was placed. Then, Al lumps were placed in a graphite crucible and superheated to $750^{\circ} \mathrm{C}$ in the presence of argon gas using a resistance heating furnace. Prior to bottom pouring, the superheated melt was stirred at $460 \mathrm{rpm}$ for $5 \mathrm{~min}$ and then through the base of the orifice of $10 \mathrm{~mm}$ diameter the melt was then passed for further. At a flow rate of $25 \mathrm{lpm}$ with two jets of argon gas the melt was disintegrated and directed to the core. At the end, an ingot of $40 \mathrm{~mm}$ diameter was developed. This ingot was later trimmed to $30 \mathrm{~mm}$ diameter and $30 \mathrm{~mm}$ length, corresponding to a volume fraction of $\sim 0.3$ for the $\mathrm{Mg}-20 \mathrm{GMB}$ core for further characterizations.

\subsection{Characterization and Testing Methods}

The density of as-cast pure $\mathrm{Al}$ and $\mathrm{Al} / \mathrm{Mg}$-20GMB hybrid composite samples was measured using Archimedes' principle. Distilled water was used as the immersion fluid. An A\&D ER-182A electronic balance (Tokyo, Japan) was used to weigh the samples (accuracy of $0.0001 \mathrm{~g}$ ). Theoretical density was calculated using the rule of mixtures. The average of 5 samples was taken.

Phase analysis was conducted on polished as-cast pure $\mathrm{Al}$ and $\mathrm{Al} / \mathrm{Mg}$-20GMB hybrid composite samples. With a scan speed of $2 \% \mathrm{~min}$ in an automated Shimadzu LAB-XRD-6000 diffractometer (Kyoto, Japan) they were exhibit to $\mathrm{CuK}_{\alpha}$ radiation $\left(\lambda=1.5406 \mathrm{~A}^{\circ}\right)$. For each composition, the analysis was conducted on 5 samples.

Microstructure and interfacial characteristics of the as-cast pure $\mathrm{Al}$ and $\mathrm{Al} / \mathrm{Mg}-20 \mathrm{GMB}$ hybrid composite were examined using Scanning Electron Microscope attached with Energy Dispersive X-Ray Spectroscopy (JEOL Ltd., JSM-6010, Tokyo, Japan). Three samples of each composition were analysed.

Microhardness measurements were made on polished as-cast pure $\mathrm{Al}$ and as-cast $\mathrm{Al} / \mathrm{Mg}-20 \mathrm{GMB}$ hybrid composite samples using Matsuzawa MXT50 automatic digital microhardness tester with Vickers indenter (Akita, Japan). An indentation load of $245.5 \mu \mathrm{N}$ and a dwell time of $15 \mathrm{~s}$ were used. For each sample, the average, as well as the standard deviation for 10 hardness readings, was taken. Three samples of each composition were used. 
Compressive properties were performed at room temperature on cylindrical as-cast pure $\mathrm{Al}$ and $\mathrm{Al} / \mathrm{Mg}-20 \mathrm{GMB}$ hybrid composite samples. The test was performed as per ASTM E9-89a. Shimadzu AG-25TB machine (Kyoto, Japan) was used to test compression samples of $30 \mathrm{~mm}$ diameter and 30 $\mathrm{mm}$ length using a strain rate of $10^{-3} \mathrm{~s}^{-1}$. Five samples of each composition were tested.

\section{Results and Discussions}

Density measurements of as-cast $\mathrm{Al}, \mathrm{Mg}$-20GMB core and $\mathrm{Al} / \mathrm{Mg}-20 \mathrm{GMB}$ hybrid composite are listed in Table 1. It can be seen that the presence of lower density GMB particles $(\sim 1.05 \mathrm{~g} / \mathrm{cc})$ in the $\mathrm{Mg}$ core material resulted in $\sim 14 \%$ reduction in density value compared to pure $\mathrm{Mg}(1.74 \mathrm{~g} / \mathrm{cc})$. Further, presence both $\mathrm{Mg}$ and $\mathrm{GMB}$ in $\mathrm{Al}$ shell effectively resulted in reduction of $\mathrm{Al}$ density by $\sim 13 \%$. Though the Mg-20GMB core materials and $\mathrm{Al} / \mathrm{Mg}-20 \mathrm{GMB}$ hybrid composites show higher porosity values than as-cast $\mathrm{Al}$ shell, the porosity for the hybrid composite still remained $<2 \%$ (near net shape). The higher porosity observed for hybrid composite can be attributed to the presence of reinforcement and the syntactic core associated porosity [35,36]. The amount of porosity present inside the hollow spheres of the syntactic foam core can be calculated using the density of standard glass $\left(\rho_{\text {glass }}=2.54 \mathrm{~g} / \mathrm{cc}\right.$ ) and true particle density of hollow GMB particles $\left(\rho_{\text {gmb }}=1.05 \mathrm{~g} / \mathrm{cc}\right)$. The ratio of inner to outer radius of hollow spheres is defined as radius ratio $\left(\eta=r_{i} / r_{0}\right)$ and is given by [37]

$$
\rho_{\text {gmb }}=\frac{\rho_{\text {glass }} \frac{4}{3} \pi\left(r_{o}^{3}-r_{i}^{3}\right)}{\frac{4}{3} \pi r_{o}^{3}}=\rho_{\text {glass }}\left(1-\eta^{3}\right)
$$

or by relating radius ratio $(\eta)$ to wall thickness [38]. The radius ratio relates to hollow sphere wall thickness as $\omega=r_{o}(1-\eta)$. The volume fraction of porosity in a hollow GMB particle can be estimated as $\phi_{H S}=\eta^{3}$. Since the total hollow GMB volume fraction in Mg-20GMB syntactic foam $(\phi)$ is 0.42 , the total porosity in the syntactic foam core is calculated as $\phi_{v}=0.42 \times \eta^{3}=0.26$. The calculation shows that the syntactic foam core contains $26 \mathrm{vol} . \%$ porosity. This porosity will be available for compaction during compressive loading.

Table 1. Density and porosity of as-cast pure Al, Mg-20GMB syntactic composite core, and as-cast $\mathrm{Al} / \mathrm{Mg}-20 \mathrm{GMB}$ hybrid composite.

\begin{tabular}{cccc}
\hline Materials & $\begin{array}{c}\text { Theoretical Density } \\
(\mathrm{g} / \mathrm{cc})\end{array}$ & $\begin{array}{c}\text { Experimental Density } \\
(\mathrm{g} / \mathrm{cc})\end{array}$ & $\begin{array}{c}\text { Porosity } \\
\mathbf{( \% )}\end{array}$ \\
\hline as-cast pure Al & 2.698 & $2.673 \pm 0.007$ & 0.93 \\
Mg-20 wt.\%GMB & 1.537 & $1.492 \pm 0.016$ & 2.93 \\
syntactic composite & & $(\downarrow 44.18 \%)$ & \\
as-cast Al/Mg-20 wt.\%GMB & 2.355 & $2.324 \pm 0.011$ & 1.31 \\
\hline
\end{tabular}

X-ray diffraction (XRD) analysis of as-cast pure $\mathrm{Al}$ (shell) and extruded Mg-20GMB (core) samples are illustrated in Figure 3. As seen in Figure 3a, the XRD pattern has four sharp peaks. Four characteristic peaks for aluminium $\left(2 \theta=38.45,44.7,65.09\right.$, and $\left.78.2^{\circ}\right)$, corresponding to Miller indices (111), (200), (220) and (311) were observed [30]. The XRD pattern in Figure 3b for the Mg-20GMB core show $\mathrm{SiO}_{2}$ and $\alpha-\mathrm{Mg}$ peaks, which is basically the chemical composition of GMB reinforcement and matrix, and no peaks matching $\mathrm{Mg}_{2} \mathrm{Si}$ were observed. However, the texture corresponding to the basal plane is still high for Mg indicating micron-sized GMB reinforcement did not result in significant texture randomization of pure $\mathrm{Mg}$.

The Field emission scanning electron microscopy (FESEM) micrographs of $\mathrm{Al}$ shell and the hybrid composite samples are shown in Figure 4a-c. The interface between the Al-shell and Mg-20GMB core in the developed $\mathrm{Al} / \mathrm{Mg}-20 \mathrm{GMB}$ hybrid composite is shown in Figure $4 \mathrm{~b}$. Two distinct regions can be observed in the micrographs of the hybrid composite; wherein the shell region shows $\mathrm{Al}$ and the Mg-20GMB syntactic foam core with white and grey phases. Additionally, a clear and intact interface 
between the shell and the core regions excluding slight debonding at some interface locations was revealed by the SEM micrograph (Figure $4 \mathrm{~b}$ ). Similarly, good interfacial bonding between the $\mathrm{Mg}$ and glass microballoons with limited reactions was observed. Further, minimally fractured GMB particles were observed indicating the adequacy of processing parameters. Figure $4 \mathrm{c}$ shows the zoomed image of the Mg-20GMB core region at higher magnification. It can be observed the GMB particles are distributed in both isolated and clustered form in the Mg matrix. Further, Energy dispersive X-ray spectroscopy (EDX) analysis was performed to identify the elements present in as-cast $\mathrm{Al}$ and $\mathrm{Al} / \mathrm{Mg}-20 \mathrm{GMB}$ hybrid composite as shown in Figure 5a,b. In the Al-based hybrid composite, the presence of magnesium, aluminium, and GMB elements (silicon and oxygen) can be confirmed by the peaks present in EDX results.

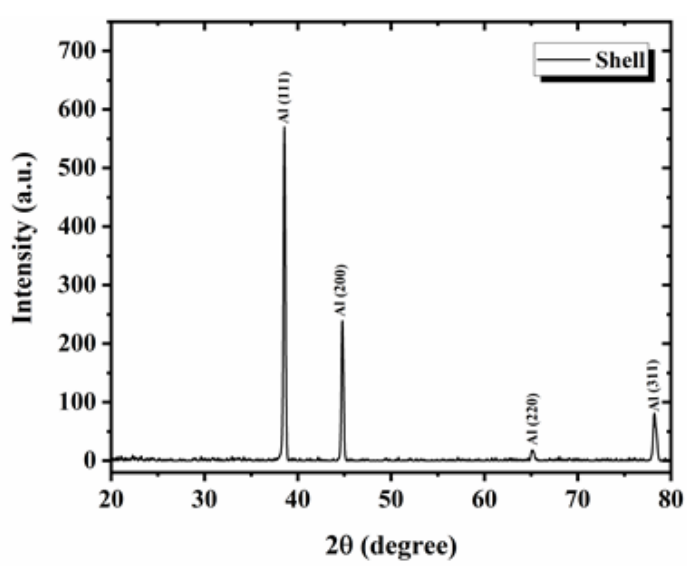

(a)

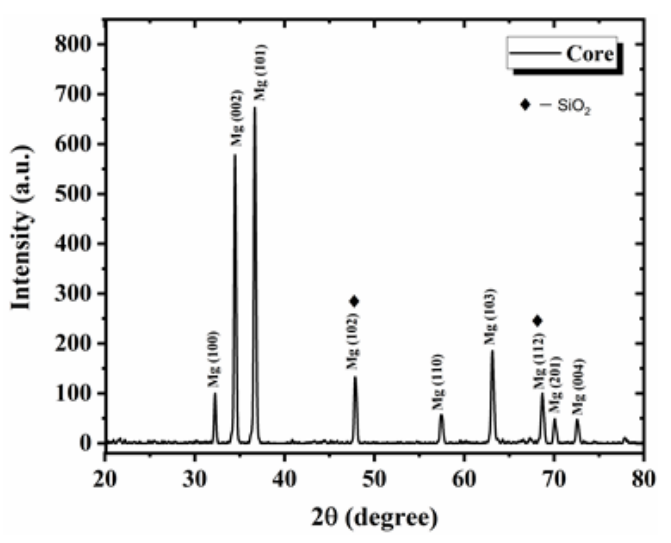

(b)

Figure 3. XRD patterns of the as-cast (a) pure $\mathrm{Al}$ (shell) and (b) Mg-20GMB material (core).
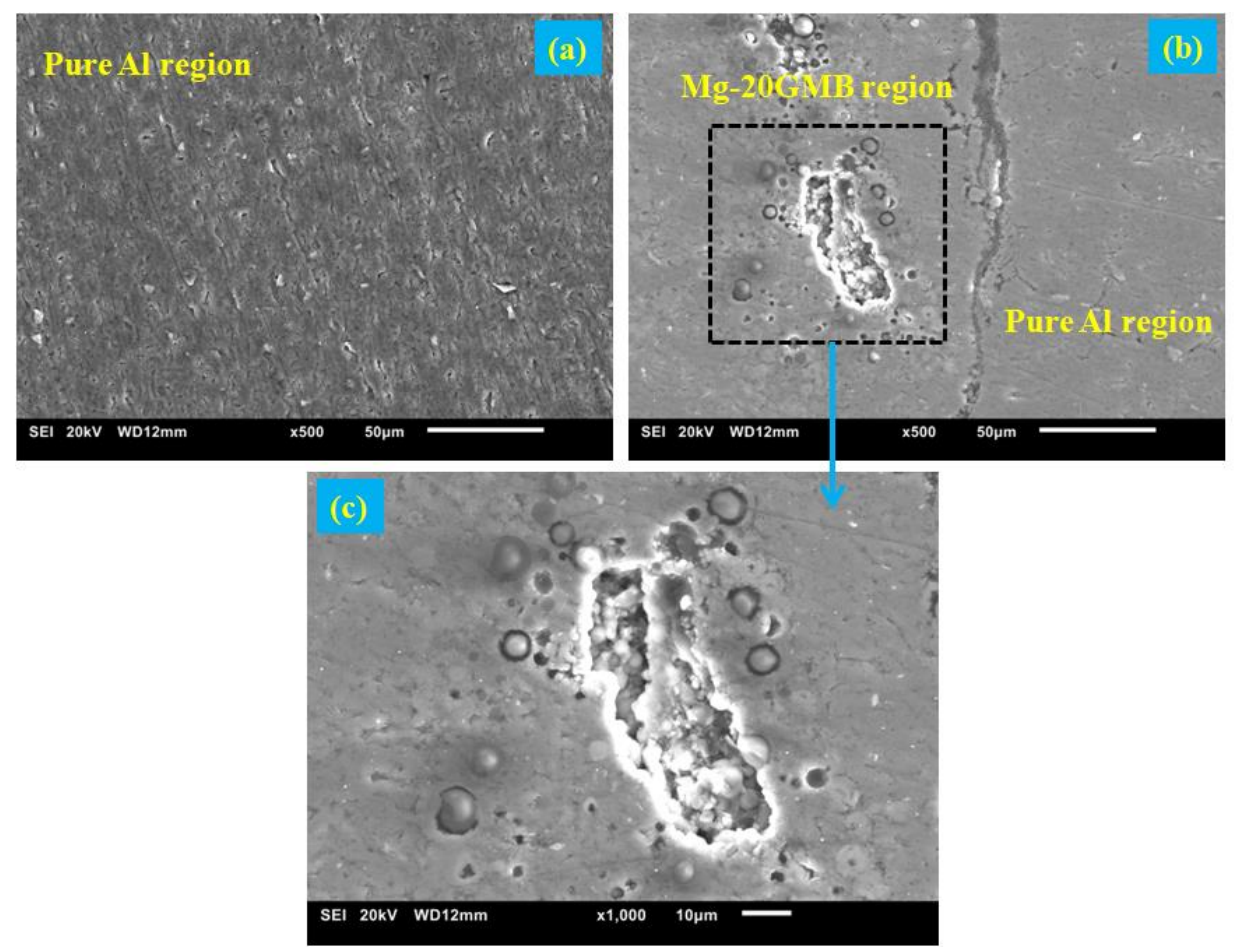

Figure 4. SEM micrographs of the as-cast (a) pure $\mathrm{Al}$, (b) Al/Mg-20GMB hybrid composite and (c) enlarged view of the rectangular portion where GMB particles can be observed in $\mathrm{Mg}$ matrix. 

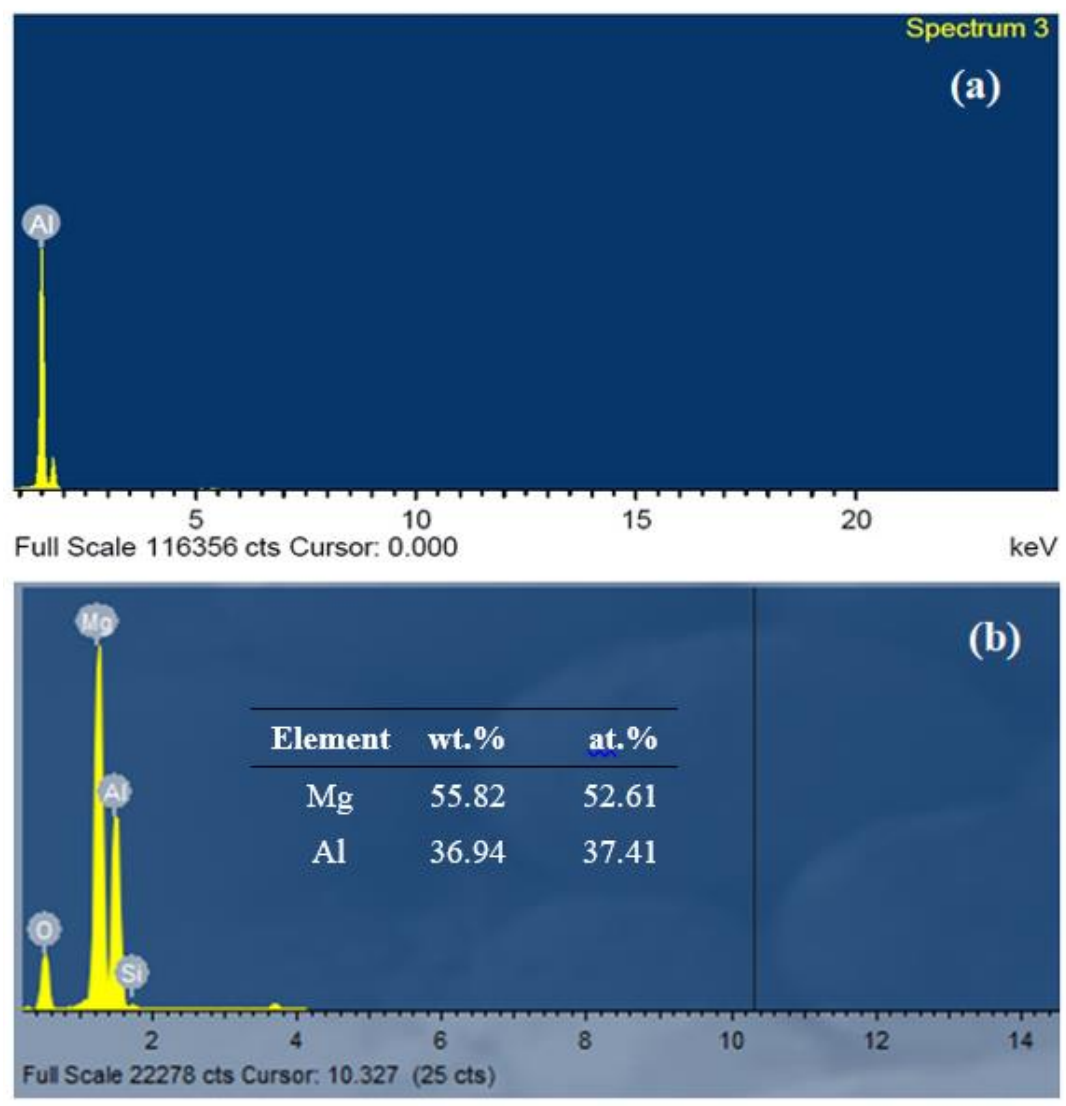

Figure 5. EDX analysis of as-cast (a) pure $\mathrm{Al}$ and (b) Al/Mg-20GMB hybrid composite.

Good interfacial integrity between the Al shell and Mg-20GMB syntactic foam core, based on the minimal presence of debonded regions and diffusion zones at the Al-Mg interface as shown in Figure 4, can be attributed to the good wettability $[8,13,39]$ and ease of solid solution formation between $\mathrm{Mg}$ and $\mathrm{Al}$ at the interface. X-ray diffraction results of extruded material did not indicate the presence of any $\mathrm{Mg}-\mathrm{Al}$ based intermetallics, as shown in Figure 3, indicating limited reaction between $\mathrm{Mg}$ and $\mathrm{Al}$ at the interface. While the intermetallics were not observed within the resolution of SEM and XRD (less than $2 \%$ by volume) techniques, their presence may not be ruled out as indicated in $\mathrm{Mg}-\mathrm{Al}$ phase diagram [40]. Accordingly, it is expected that if intermetallics are formed, their size and volume fractions will be very small. Further work is continuing in this area.

Microhardness was measured on as-cast pure $\mathrm{Al}$, shell, core, and the interface regions of as-cast $\mathrm{Al} / \mathrm{Mg}$-20GMB hybrid composite samples and the data is listed in Table 2. The microhardness for as-cast pure $\mathrm{Al}$ was $57 \pm 2 \mathrm{HV}$. The Mg-20GMB syntactic core exhibited the highest hardness value $(174 \pm 5 \mathrm{HV})$ compared to the Al shell and the interface (109 $\pm 2 \mathrm{HV})$ regions. Relatively higher microhardness of interface, when compared to pure $\mathrm{Al}$, can be attributed to strain localization coupled with solid solution strengthening [41].

Table 2. Microhardness values for as-cast samples.

\begin{tabular}{cccc}
\hline Materials & \multicolumn{3}{c}{ Microhardness (HV) } \\
& Shell Region & Core Region & Interface Region \\
\hline Pure Al & $57 \pm 2$ & - & - \\
Al/Mg-20GMB hybrid composite & $68 \pm 4$ & $174 \pm 5$ & $109 \pm 2$ \\
\hline
\end{tabular}

Compression tests were performed on a $30 \mathrm{~mm}$ diameter and $30 \mathrm{~mm}$ length of as-cast samples. The compression stress-strain curves of the as-cast pure $\mathrm{Al}$ and $\mathrm{Al} / \mathrm{Mg}$-20GMB hybrid composite samples are illustrated in Figure 6a and the obtained results are quantified in Table 3. As-cast Al/Mg-20GMB 
hybrid composite exhibited compressive yield strength (CYS) $~ 86 \pm 2 \mathrm{MPa}$ and ultimate compressive strength (UCS) $\sim 352 \pm 3 \mathrm{MPa}$, which are much higher than that of as-cast pure aluminium, CYS $\sim 52 \pm$ $5 \mathrm{MPa}$ and UCS $\sim 220 \pm 4 \mathrm{MPa}$. When compared to pure Al, significant improvements in CYS and UCS of $65.4 \%$ and $60 \%$, respectively, in the Al/Mg-20GMB hybrid composite indicate that the presence of core strongly enhanced the compression response of aluminium. Further, an $84 \%$ increase in the specific compressive strength observed for $\mathrm{Al} / \mathrm{Mg}-20 \mathrm{GMB}$ hybrid composite compared to that of pure $\mathrm{Al}$ signifies the weight-saving potential of using a magnesium syntactic foam core. The compressive properties of $\mathrm{Al} / \mathrm{Mg}$-20GMB hybrid composite is superior or even comparable with other $\mathrm{Al} / \mathrm{Mg}$ hybrid composite reported even at significantly lower density values $(\sim 13 \%)$. Furthermore, it can be seen from Table 3 that incorporation of Mg-20GMB syntactic foam core in the hybrid composite resulted in $\sim 26 \%$ increase in energy absorption capability during compressive loading compared to pure $\mathrm{Al}$.
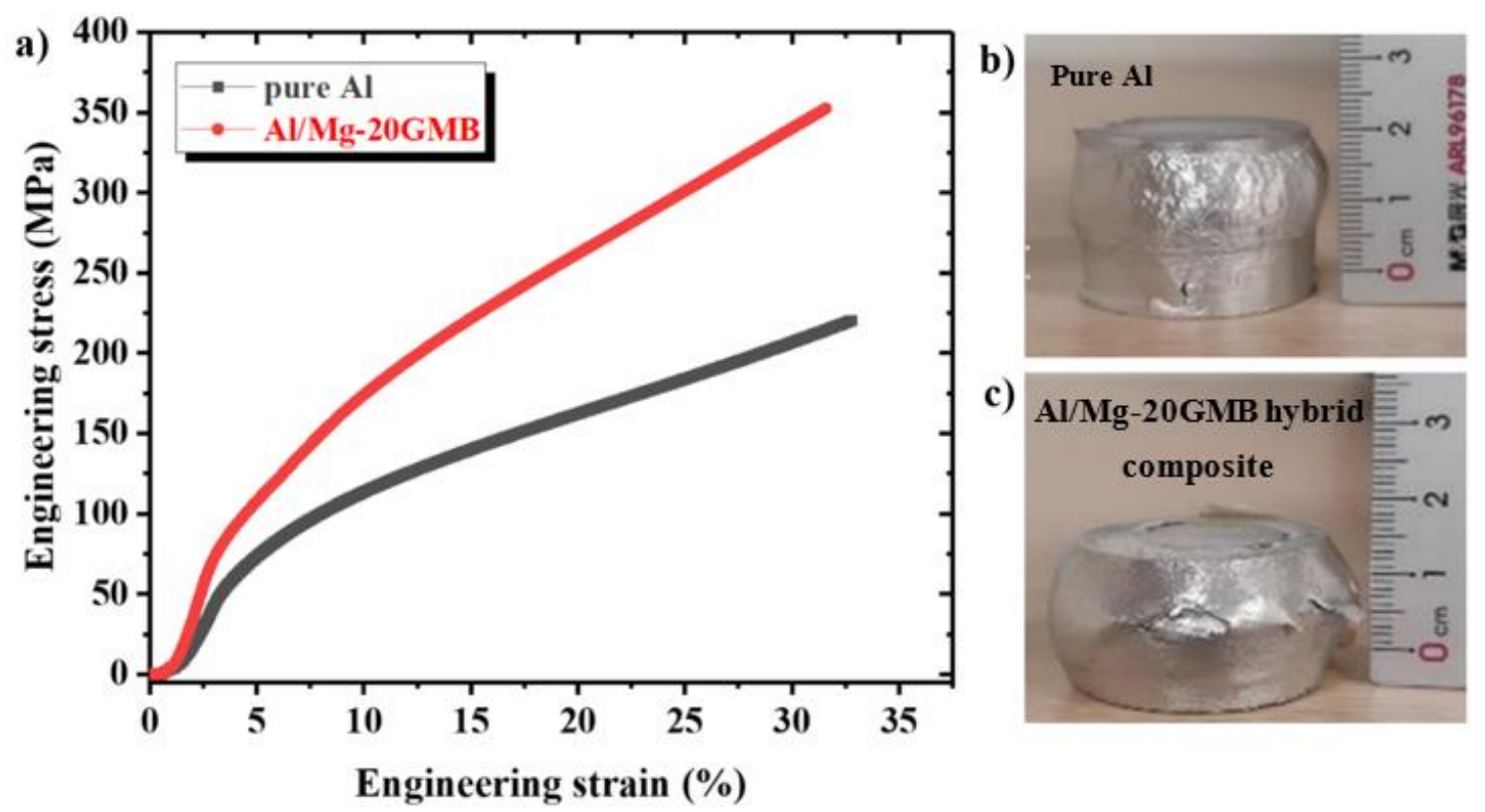

Figure 6. (a) Stress-strain curves for as-cast pure $\mathrm{Al}$ and $\mathrm{Al} / \mathrm{Mg}$-20GMB hybrid composite under compression loading. $(\mathbf{b}, \mathbf{c})$ The corresponding picture of fracture specimen after compression.

Table 3. Compression properties of as-cast pure $\mathrm{Al}$ and $\mathrm{Al} / \mathrm{Mg}-20 \mathrm{GMB}$ hybrid composite.

\begin{tabular}{|c|c|c|c|c|c|}
\hline Sample & CYS (MPa) & UCS (MPa) & $\begin{array}{c}\text { Failure Strain } \\
(\%)\end{array}$ & $\begin{array}{c}\text { Energy Absorbed } \\
\left(\mathrm{MJ} / \mathrm{m}^{3}\right)\end{array}$ & $\begin{array}{l}\text { Specific Compressive } \\
\text { Strength }(\mathrm{MPa} / \mathrm{g} / \mathrm{cc})\end{array}$ \\
\hline As-cast pure $\mathrm{Al}$ & $52 \pm 5$ & $220 \pm 4$ & $>33$ & $44.7 \pm 1.4$ & 82.3 \\
\hline $\begin{array}{c}\text { As-cast } \\
\text { Al/Mg-20GMB } \\
\text { hybrid composite }\end{array}$ & $\begin{array}{c}86 \pm 2 \\
(\uparrow 65.4 \%)\end{array}$ & $\begin{array}{l}352 \pm 3 \\
(\uparrow 60 \%)\end{array}$ & $>33$ & $\begin{array}{c}56.6 \pm 1.1 \\
(\uparrow 26.6 \%)\end{array}$ & $\begin{array}{c}151.5 \\
(\uparrow 84 \%)\end{array}$ \\
\hline $\begin{array}{c}\text { Al 1100/AZ31 } \\
\text { hybrid composite }\end{array}$ & $25-81$ & $106-335$ & - & - & - \\
\hline
\end{tabular}

Both as-cast pure $\mathrm{Al}$ and $\mathrm{Al} / \mathrm{Mg}$-20GMB hybrid composite samples showed the ductile nature of the fracture. No difference in fractured surfaces between the as-cast pure $\mathrm{Al}$ and $\mathrm{Al} / \mathrm{Mg}-20 \mathrm{GMB}$ hybrid composite was observed as both samples deformed without fracture to high strain as shown in Figure $6 b, c$.

\section{Conclusions}

As-cast pure $\mathrm{Al}$ and $\mathrm{Al} / \mathrm{Mg}$-20GMB hybrid composite materials were developed using a combination of solid and liquid metallurgy methods and their microstructure and mechanical properties have been investigated. The major findings are as follows: 
- $\quad$ The Mg-20GMB syntactic composite core material was successfully synthesized by a novel processing approach using a combination of compaction and hot extrusion.

- Pure $\mathrm{Al}$ and $\mathrm{Al} / \mathrm{Mg}-20 \mathrm{GMB}$ hybrid composite samples were successfully produced by the disintegrated melt deposition (DMD) technique.

- When compared to as-cast pure aluminium with a slight increase in the porosity, as-cast $\mathrm{Al} / \mathrm{Mg}$-20GMB hybrid composite showed a decline in experimental density $(\sim 13 \%)$ due to the presence of Mg-20GMB.

- Reasonably good GMB/Mg and Mg-GMB/Al interfacial bonding was observed as evidenced by the limited reaction zones seen along the interface.

- The Mg-20GMB core exhibited higher hardness value (174 $\pm 5 \mathrm{HV})$ compared to the Al shell and the interface regions.

- The yield strength and ultimate compressive strength of as-cast $\mathrm{Al} / \mathrm{Mg}$-20GMB hybrid composite were enhanced by $65.4 \%$ and $60 \%$, respectively. Both $\mathrm{Al}$ and hybrid composite did not fail till $33 \%$ engineering strain. Hybrid composite exhibited $26 \%$ increase in the energy absorption capability that is reflection of his enhanced static toughness.

Author Contributions: Conceptualization, M.G., B.W.C. and S.C.K.W.; Methodology, J.G.Y.S. and P.R.M.; Data curation, J.G.Y.S. and P.R.M.; Writing-Original draft preparation, P.R.M.; Investigation, G.P. and V.M.; Supervision, M.G.; Writing-Reviewing and Editing, G.M., P.R.M., G.P. and V.M. All authors have read and agreed to the published version of the manuscript.

Funding: This research was funded by the Agency for Science, Technology, and Research (A*STAR), Singapore, under its programme "Manufacturing of lightweight free-form shell, sandwich, and hybrid cellular structures for aerospace component manufacturing and repair" (WBS \# R 265000638 305).

Conflicts of Interest: The authors declare that there is no conflict of interest.

\section{References}

1. Matli, P.R.; Sheng, J.G.Y.; Parande, G.; Manakari, V.; Chua, B.W.; Wong, S.C.K.; Gupta, M. A New Method to Lightweight Magnesium Using Syntactic Composite Core. Appl. Sci. 2020, 10, 4773. [CrossRef]

2. Vicario, I.; Crespo, I.; Plaza, L.M.; Caballero, P.; Idoiaga, I.K. Aluminium Foam and Magnesium Compound Casting Produced by High-Pressure Die Casting. Metals 2016, 6, 24. [CrossRef]

3. Manakari, V.; Parande, G.; Gupta, M. Selective laser melting of magnesium and magnesium alloy powders: A review. Metals 2017, 7, 2. [CrossRef]

4. Reddy, M.P.; Ubaid, F.; Shakoor, R.; Parande, G.; Manakari, V.; Mohamed, A.; Gupta, M. Effect of reinforcement concentration on the properties of hot extruded Al-Al2O3 composites synthesized through microwave sintering process. Mater. Sci. Eng. A 2017, 696, 60-69. [CrossRef]

5. Parande, G.; Manakari, V.; Kopparthy, S.D.S.; Gupta, M. A study on the effect of low-cost eggshell reinforcement on the immersion, damping and mechanical properties of magnesium-zinc alloy. Compos. Part B Eng. 2020, 182, 107650. [CrossRef]

6. Li, G.; Yang, W.; Jiang, W.; Guan, F.; Jiang, H.; Wu, Y.; Fan, Z. The role of vacuum degree in the bonding of $\mathrm{Al} / \mathrm{Mg}$ bimetal prepared by a compound casting process. J. Mater. Process. Technol. 2019, 265, 112-121. [CrossRef]

7. Feng, B.; Xin, Y.; Guo, F.; Yu, H.; Wu, Y.; Liu, Q. Compressive mechanical behavior of Al/Mg composite rods with different types of Al sleeve. Acta Mater. 2016, 120, 379-390. [CrossRef]

8. Paramsothy, M.; Srikanth, N.; Gupta, M. Solidification processed Mg/Al bimetal macrocomposite: Microstructure and mechanical properties. J. Alloys Compd. 2008, 461, 200-208. [CrossRef]

9. Elanchezhian, C.; Bhaskar, G.; Vivekanandhan, M. An Investigation of the Mechanical Properties of HybridComposites in Applications of Automotive Industry. Mater. Today Proc. 2019, 16, 875-882. [CrossRef]

10. Ibrahim, I.; Mohamed, F.; Lavernia, E. Particulate reinforced metal matrix composites-A review. J. Mater. Sci. 1991, 26, 1137-1156. [CrossRef]

11. Matli, P.R.; Ubaid, F.; Shakoor, R.A.; Parande, G.; Manakari, V.; Yusuf, M.; Mohamed, A.M.A.; Gupta, M. Improved properties of $\mathrm{Al}-\mathrm{Si}_{3} \mathrm{~N}_{4}$ nanocomposites fabricated through a microwave sintering and hot extrusion process. RSC Adv. 2017, 7, 34401-34410. [CrossRef] 
12. Mazahery, A.; Ostadshabani, M. Investigation on mechanical properties of nano-Al2O3-reinforced aluminum matrix composites. J. Compos. Mater. 2011, 45, 2579-2586. [CrossRef]

13. Paramsothy, M.; Gupta, M.; Srikanth, N. Processing, microstructure, and properties of a Mg/Al bimetal macrocomposite. J. Compos. Mater. 2008, 42, 2567-2584. [CrossRef]

14. Brendan, T.Z.M.; Parande, G.; Manakari, V.; Gupta, M. Using low-temperature sinterless powder method to develop exceptionally high amount of zinc containing $\mathrm{Mg}-\mathrm{Zn}-\mathrm{Ca}$ alloy and $\mathrm{Mg}-\mathrm{Zn}-\mathrm{Ca} / \mathrm{SiO} 2$ nanocomposite. J. Alloys Compd. 2020, 853, 156957.

15. Akinwamide, S.O.; Abe, B.T.; Akinribide, O.J.; Obadele, B.A.; Olubambi, P.A. Characterization of microstructure, mechanical properties and corrosion response of aluminium-based composites fabricated via casting-A review. Int. J. Adv. Manuf. Technol. 2020, 109, 975-991. [CrossRef]

16. Reddy, M.P.; Manakari, V.; Parande, G.; Shakoor, R.; Mohamed, A.; Gupta, M. Structural, mechanical and thermal characteristics of Al-Cu-Li particle reinforced Al-matrix composites synthesized by microwave sintering and hot extrusion. Compos. Part B Eng. 2019, 164, 485-492. [CrossRef]

17. Manakari, V.; Parande, G.; Doddamani, M.; Gupta, M. Evaluation of wear resistance of magnesium/glass microballoon syntactic foams for engineering/biomedical applications. Ceram. Int. 2019, 45, 9302-9305. [CrossRef]

18. Omar, M.Y.; Xiang, C.; Gupta, N.; Strbik, O.M.; Cho, K. Syntactic foam core metal matrix sandwich composite under bending conditions. Mater. Des. 2015, 86, 536-544. [CrossRef]

19. Read, S. Aerofoil and a Method of Manufacturing an Aerofoil. U.S. Patent 7594325B2, 29 September 2009.

20. Manakari, V.; Parande, G.; Doddamani, M.; Gupta, M. Enhancing the ignition, hardness and compressive response of magnesium by reinforcing with hollow glass microballoons. Materials 2017, 10, 997. [CrossRef]

21. Manakari, V.; Parande, G.; Gupta, M. Effects of hollow fly-ash particles on the properties of magnesium matrix syntactic foams: A review. Mater. Perform. Charact. 2016, 5, 116-131. [CrossRef]

22. Xu, G.; Luo, A.A.; Chen, Y.; Sachdev, A.K. Interfacial phenomena in magnesium/aluminum bi-metallic castings. Mater. Sci. Eng. A 2014, 595, 154-158. [CrossRef]

23. Zhang, J.; Luo, G.; Wang, Y.; Shen, Q.; Zhang, L. An investigation on diffusion bonding of aluminum and magnesium using a Ni interlayer. Mater. Lett. 2012, 83, 189-191. [CrossRef]

24. Guan, F.; Jiang, W.; Li, G.; Jiang, H.; Zhu, J.; Fan, Z. Interfacial bonding mechanism and pouring temperature effect on Al/Cu bimetal prepared by a novel compound casting process. Mater. Res. Express 2019, 6, 096529. [CrossRef]

25. Song, X.; Sun, J.; Zhong, D.; Yu, Y.; Wang, T.; Cao, Z.; Li, T. Study on Al/Mg compound materials by solid-liquid bonding method. Mater. Res. Innov. 2012, 16, 51-55. [CrossRef]

26. Zhao, K.; Xu, D.; Li, H.; Zhang, J.; Chen, D. Microstructure and mechanical properties of Mg/Mg bimetal composites fabricated by hot-pressing diffusion and co-extrusion. Mater. Sci. Eng. A 2019, 764, 138194. [CrossRef]

27. Emami, S.; Divandari, M.; Hajjari, E.; Arabi, H. Comparison between conventional and lost foam compound casting of Al/Mg light metals. Int. J. Cast Met. Res. 2013, 26, 43-50. [CrossRef]

28. Hajjari, E.; Divandari, M.; Razavi, S.; Emami, S.; Homma, T.; Kamado, S. Dissimilar joining of Al/Mg light metals by compound casting process. J. Mater. Sci. 2011, 46, 6491-6499. [CrossRef]

29. Hajjari, E.; Divandari, M.; Razavi, S.; Homma, T.; Kamado, S. Intermetallic compounds and antiphase domains in $\mathrm{Al} / \mathrm{Mg}$ compound casting. Intermetallics 2012, 23, 182-186. [CrossRef]

30. Nie, X.; Liu, J.; Li, H.; Du, Q.; Zhang, J.; Zhuang, L. An investigation on bonding mechanism and mechanical properties of $\mathrm{Al} / \mathrm{Ti}$ compound materials prepared by insert moulding. Mater. Des. 2014, 63, 142-150. [CrossRef]

31. He, K.; Zhao, J.; Li, P.; He, J.; Tang, Q. Investigation on microstructures and properties of arc-sprayed-Al/AZ91D bimetallic material by solid-liquid compound casting. Mater. Des. 2016, 112, 553-564. [CrossRef]

32. Liu, T.; Wang, Q.; Sui, Y.; Wang, Q.; Ding, W. An investigation into aluminum-aluminum bimetal fabrication by squeeze casting. Mater. Des. 2015, 68, 8-17. [CrossRef]

33. Rübner, M.; Günzl, M.; Körner, C.; Singer, R. Aluminium-aluminium compound fabrication by high pressure die casting. Mater. Sci. Eng. A 2011, 528, 7024-7029. [CrossRef]

34. Gupta, M.; Parande, G.; Manakari, V. An insight into high performance magnesium alloy/nano-metastable-syntactic composites. In Proceedings of the 17th Australian International Aerospace Congress, AIAC, Melbourne, Australia, 26-28 February 2017; p. 270. 
35. Ghosh, P.; Ray, S. Effect of porosity and alumina content on the mechanical properties of compocast aluminium alloy-alumina particulate composite. J. Mater. Sci. 1986, 21, 1667-1674. [CrossRef]

36. Suneesh, E.; Sivapragash, M. Comprehensive studies on processing and characterization of hybrid magnesium composites. Mater. Manuf. Process. 2018, 33, 1324-1345. [CrossRef]

37. Tagliavia, G.; Porfiri, M.; Gupta, N. Vinyl ester-Glass hollow particle composites: Dynamic mechanical properties at high inclusion volume fraction. J. Compos. Mater. 2009, 43, 561-582. [CrossRef]

38. Luong, D.D.; Strbik, O.M., III; Hammond, V.H.; Gupta, N.; Cho, K. Development of high performance lightweight aluminum alloy/SiC hollow sphere syntactic foams and compressive characterization at quasi-static and high strain rates. J. Alloys Compd. 2013, 550, 412-422. [CrossRef]

39. Paramsothy, M.; Hassan, S.; Srikanth, N.; Gupta, M. Toughening mechanisms in Mg/Al macrocomposites: Texture and interfacial mechanical interlocking. J. Phys. D Appl. Phys. 2008, 41, 175402. [CrossRef]

40. Avedesian, M.M.; Baker, H. ASM Specialty Handbook: Magnesium and Magnesium Alloys; ASM International: Materials Park, OH, USA, 1999.

41. Zheng, S.; Wang, J.; Carpenter, J.; Mook, W.; Dickerson, P.; Mara, N.; Beyerlein, I. Plastic instability mechanisms in bimetallic nanolayered composites. Acta Mater. 2014, 79, 282-291. [CrossRef]

(C) 2020 by the authors. Licensee MDPI, Basel, Switzerland. This article is an open access article distributed under the terms and conditions of the Creative Commons Attribution (CC BY) license (http://creativecommons.org/licenses/by/4.0/). 